\title{
ÉCFRASIS Y ENARGEIA EN LA METAMORFOSIS (ASNO DE ORO) DE APULEYO: LA ESCULTURA DE DIANA Y ACTEÓN COMO MISE EN ABYME
}

\author{
Écfrasis and enargeia in Metamorphosis (Asno de Oro) of Apuleius: \\ The sculpture of Diana and Actaeon as mise en abyme
}

\section{Minor Herrera Valenciano*}

\begin{abstract}
RESUMEN
Este trabajo hace ver cómo la écfrasis no solo se limita a la creación de un texto a partir de la observación detallada de una obra artística (escultura de Diana y Acteón), o a la descripción de esta por medio de ilustrativas y hermosas imágenes más bien, lo que se propone a continuación versa sobre cuál es la función de la práctica ecfrástica inscrita en un texto literario, cuáles son las intenciones que posee el autor para entrelazar, como urdimbre en el tejido (texto), la écfrasis y finalmente qué papel juega la enargeia presente en la écfrasis por analizar.

Palabras clave: Écfrasis, Enargeia, Descripción, Escultura, Texto.
\end{abstract}

\begin{abstract}
This work allows to see how the ekphrasis is not just limited to the creation of a text starting from the detailed observation of an artistic work (sculpture of Diana and Actaeon), or description of it through beutiful images, what it's going to be proposed treat about what is the function of the ekphrastic practice registered in a literary text, which are the instentions that the owthor interlock how warp in the web, the ekphrasis and finally what is the roll that the enargeia plays in the actual ekphrasis that is going to be analyzed.
\end{abstract}

Key Words: Ekphrasis, Enargeia, Descreption, Sculpture, Text.

Universidad de Costa Rica. Sede de Occidente. Costa Rica

Correo electrónico: minorj2007@hotmail.com

Recepción: 7/8/2014. Aceptación: 17/3/15. 


\section{Introducción}

La conceptualización de la palabra écfrasis, generalmente, ha sido fundamentada a partir de su referencialidad con los tratados de retórica, siendo así, que se le restringe con el término latino de descriptio; sin embargo, es necesario tener en cuenta que la écfrasis es más que una descripción detallada de un objeto o de una persona. Ahora bien, dicha afirmación no basta, pues abría que definirla desde la función que posee, la cual es mucho más especializado, ya que funge para designar la práctica literaria de describir un objeto de arte de forma extremadamente detallada, a esa definición es la que señala Horacio en su Arte Poética (p.361) al afirmar que la écfrasis es " $u t$ pictura poesis".

Este trabajo hace ver cómo la écfrasis no solo se limita a la creación de un texto a partir de la observación detallada de una obra artística o a la descripción de esta por medio de ilustrativas y hermosísimas imágenes, más bien, lo que se propone a continuación versa sobre cuál es la función de la práctica ecfrástica inscrita en un texto literario, cuáles son las intenciones que posee el autor al entrelazar, como urdimbre en el tejido (texto), la écfrasis y finalmente qué papel juega la enargeia presente en la écfrasis del grupo escultórico de Diana y Acteón que se analizará.

Para tales fines, será necesario dirigir todos los esfuerzos hacia el análisis del capítulo II de la Metamorfosis o Asno de Oro, del escritor romano Apuleyo, en donde se presenta una descripción del grupo escultórico de Diana y Acteón. Este último llama mucho la atención no solo debido a que es una obra de arte descrita hermosamente en un texto que, por principio, tiende a satirizar todo lo que la sociedad romana contextualizada en él estaba viviendo, sino porque dicha descripción constituirá, como se pretenderá demostrar en el desarrollo de este trabajo de investigación, la puesta en abismo que nos indicará lo que al personaje principal del texto (Lucio) le sucederá.

Finalmente, cabe destacar que la écfrasis será vista como una herramienta que, en manos de Apuleyo ofrecerá muchas posibilidades para la inclusión de digresiones, por medio de las cuales le conferirá profundidad al relato, le permitirá realizar juegos temporales o espaciales $\mathrm{y}$, por supuesto, le permitirá al lector anticipar algunos datos que le ayudarán (o complementarán) a la comprensión final del texto.

\section{Perspectiva teórica: Mise en abyme}

El primer concepto que es necesario definir es el de mise en abyme o "puesta en abismo", ya que es basado en este que se tratará de comprobar que la écfrasis mostrada en el Libro II de "La Metamorfosis o Asno de Oro" de Apuleyo funciona o no como eso (mise en abyme). Dicho concepto surge, según Dällenbach (1991), en la obra de Gide y a partir del Nouveau Roman y podría entenderse dicho concepto, metafóricamente, como una "muñeca rusa" (matrioska), dentro de la cual hay una más pequeña, que representa o es ideántica a la más grande que la contine. Gide, citado por Dällenbach (1991), se apoya en las pinturas de Velázquez y algunos artistas del barroco, por el juego de espejos que estos realizan y propone, para hacer referencia a la mise en abyme, lo siguiente:

\footnotetext{
Me complace no poco el hecho de que en una obra de arte aparezca así trasladado, a escala de personajes, el propio sujeto de la obra. Así, en algunos cuadros [...], un espejito convexo y sombrío, refleja, a su vez, el interior de la estancia en que se desarrolla la escena pintada [...] Mucho más sería, mucho mejor expresaría lo que quise decir en mis Cahiers, en mi Narcise y en La tentative, la comparación con el procedimiento heráldico consistente en colocar, dentro del primero, un segundo "en abyme" (p.15)
}

Por otra parte, Dällenbach (1991: 16) define la puesta en abismo como un "enclave que guarde relación de similitud con la obra que lo contiene". Ahora bien, el concepto que Gide propone, lo hace sirviéndose de la heráldica, arte que se encarga de explicar y describir con mucha sutileza los escudos de armas y dentro de los cuales, un escudo mayor contiene en su centro otro más pequeño, pero que hace referencia al 
más grande. Esa característica de replicarse a sí mismo podría hacer relación con la propuesta de Lacán en la que "el emisor recibe del receptor su propio mensaje en forma invertida" (Dällenbach; 1991: 22).

Unido a lo anterior, Dällenbach (1991) define, fundamentalmente, la mise en abyme, como la imagen reflejada de todo el texto en un fragmento de él mismo, es decir, que habrá ciertos pasajes en los textos que harán que este se vea reflejado en ellos.

Sin embargo, existen algunos estudiosos que amplían el concepto, tal es caso de Jean Ricardou, citado por Meyer-Minnerman (2004), quien afirmaba que no solo aquellos elementos que evidentemente se relacionan a manera de reflejo con otros funcionan como mise en abyme, sino que existen otros que aparentan no ser tan importantes, pero que también constituyen maneras de realizar una puesta en abismo. A dicha afirmación se le une la de Elene Beristain (1995), quien propone que es posible que la mise en abyme se pueda llevar a cabo no solo a partir de una pequeño fragmento sino que podría desarrollarse partiendo de un texto completo inserto dentro de otro más amplio.

Es un hecho, entonces, que un metarrelato se constituiría como una mise en abyme, pero no sucede lo contrario, es decir, no toda mise en abyme constituirá un metarrelato. De este modo, la puesta en abismo se puede realizar a partir de un elemento evocador, sea una imagen, un verso, una descripción y no necesariamente como un texto inscrito dentro de otro.

Visto de otra manera, la mise en abyme es un entrelazamiento de múltiples estructuras narrativas que se podrían manifestar dentro de un texto, pero ahí no acaba la definición de dicho término, ya que según Carwell, citado por Gabrielle (2005), la mise en abyme es una especie de pistas que forman parte de la estructura del texto y que, hasta cierto modo, da indicios de que lo que sucederá a los personajes o de lo que en la trama general de la historia podría ocurrir.

Para favorecer la amplitud del trabajo se procederá a categorizar la mise en abyme, de esta manera encontramos dos tipos según Dällenbach (1991):
La mise en abyme se manifiesta, en un primer momento, a partir del enunciado, también es llamada ficcional. Además, es definida por él como "cita de contenido y resumen intratextual" (p.73), es decir, se puede notar cómo dentro de un texto se manifiestan algunos enunciados que hacen referencia al texto mismo en que se encuentran. Dicha interacción entre enunciados y texto consolidará el entramado textual y acrecentará la significación del mismo.

Son tres las propuestas en las que la mise en abyme suele apoyarse:

El primero radica en el hecho de que la mise en abyme se puede presentar como un solo fragmento (su extensión será de una página o más) o dividiéndola e intercalándola en varios pasajes del texto.

El segundo considera que la mise en abyme tiene una función reveladora en el texto, es decir, que colabora con la trama textual en general aclarando algunos pasajes que, de otro modo, parecerían oscuros o indescifrables para el lector.

El tercero señala que la mise en abyme debe controlar la temporalidad del texto en el cual se inscribe, ya que de no ser así la puesta en abismo, al ser un segmento narrativo, tendrá una ubicación temporal dentro de otro texto narrativo que posee la propia, lo cual terminaría generando un problema cronológico.

En una segunda instancia, la mise en abyme se refiere no a los fragmentos de la narración que hacen referencia a otros, sino que se enfoca en un nivel de profundidad mayor, de esta manera se desarrolla en la enunciación. Este tipo de mise en abyme, según Dällenbach (1991), "pone en escena tanto el agente como el propio proceso de producción de la siguiente manera". (p.95)

Lo anterior hace referencia a que la puesta en abismo debe estar enfocada en varias relaciones, es decir, si pone en escena al agente y al proceso de producción, tendrá que existir entonces una relación estrecha entre el narrador y el creador del texto, lo cual dará como resultado el hecho de que la producción de la mise en abyme sea un mecanismo que servirá para hacer notorio lo que de otro modo sería invisible. 
En fin, la mise en abyme radica básicamente en la referencialidad creada en lo interno del texto, es decir, fragmentos que dentro del relato reflejan otras partes, personajes o pasajes del texto que las contiene. Sin embargo, debe quedar claro que, contrario al metarrelato, la mise en abyme puede ser una imagen, un signo, una descripción de una imagen, una estatua y no solamente un texto literario dentro de otro texto que lo abarca hasta absorberlo dentro de su propia trama.

\subsection{La écfrasis}

Otro concepto que es indispensable recurrir, es el de écfrasis. Al respecto, Pineda (2000) inicia con el concepto más antiguo, el de écfrasis visto únicamente como la mera descripción vívida que se hace de un objeto, es decir, un tipo de representación que es capaz de poner frente a los ojos del receptor el objeto descrito.

Pineda (2000) parafrasea a Hermógenes (siglos II-III) para definir la écfrasis de la siguiente manera:

composición que expone en detalle de una manera manifiesta [...] y que presenta ante los ojos el objeto mostrado, y añade que hay écfrasis de personajes, de hechos, de circunstancias, de lugares, de épocas y de otros muchos objetos (p. 252).

Tal como se nota, la écfrasis es una descripción, pero no de cualquier tipo, sino una que pone de manifiesto, debido a la viveza de esta, lo detallado, en otras palabras, mediante la descripción, el objeto se muestra en las imágenes mentales del receptor tal cual fue observado por quien lo describe.

Según la cita anterior, écfrasis se limitaría a ser una simple descripción de un objeto, sin embargo, dicha limitación se rompe con lo testimoniado por Spitzer (1967: 67), quien afirma que la écfrasis es más que la descripción de un objeto, es "la descripción poética de una obra de arte pictórica o escultural".

Ese proceso de descripción de una obra de arte, en reiteradas ocasiones funciona como un enriquecedor del texto, siempre que se manifieste como metarrelato o como mise en abyme. Al respecto Pineda (2000) manifiesta lo siguiente:

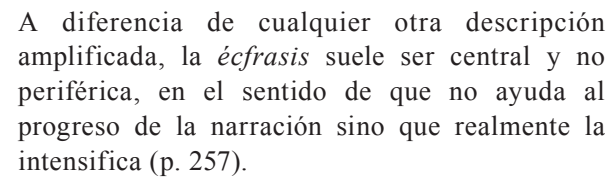
amplificada, la écfrasis suele ser central y no periférica, en el sentido de que no ayuda al progreso de la narración sino que realmente la intensifica (p. 257).

Es claro, entonces, que el valor de la écfrasis es incalculable cuando, además de describir una obra de arte, se encuentra (ella misma) inscrita dentro de una obra literaria mayor para la cual funciona como un enunciado amplificador del sentido del texto.

Finalmente, según Pineda (2000), existen varias consideraciones para estudiar la écfrasis, las cuales han sido sitetizadas de la siguiente manera:

a- La écfrasis no tiene por qué hacer referencia a un objeto real.

b- Puede que lo descrito por la écfrasis no sea una obra de arte sino un paisaje o alguna escena natural que llame la atención del escritor.

c- Algunos casos de écfrasis de un objeto real causa que se dé una doble intertextualidad la que enlaza todo el texto con otros y, por supuesto, con su referente visual.

d- La existencia de la écfrasis de cuadros imaginarios subraya el carácter autónomo de estos textos.

e- La écfrasis llamará la atención del receptor debido a que la descripción detallada de la obra de arte lo hará reflexionar acerca del texto mismo como de lo descrito.

Écfrasis será entendida, finalmente, para efectos de este artículo, como una descripción de un objeto de arte, pero cuya función va más allá de la mera descripción para dar paso a una estructura textual importante para dilucidar las intenciones o los significados del texto.

\subsection{La enargeia}

La enargeia ha sido traducida simplemente como evidentia en la retórica 
latina. Dicho término aparece frecuentemente en los tratados, cuando se mencionan cuestiones concernientes a la vivacidad con que se exponen los hechos narrados.

Ante las consideraciones anteriores, es necesario tener en cuenta que la écfrasis dependerá de la enargeia con que esta se realice. Este concepto (enargeia) no es tanto una propiedad del lenguaje en sí, sino una habilidad del sujeto enunciador, es decir, tiene que ver con la destreza en la selección verbal y con la capacidad imaginativa, ya que estas dos son fundamentales para las pretensiones de crear imágenes visuales mediante las palabras.

De este modo, la enargeia se reviste de un valor elemental, pues es por medio de esta que la écfrasis causará o no un impacto en el receptor.

Al respecto, Aristóteles (2009) afirma en su Poética (1455 a), lo siguiente:

Es preciso urdir la trama de los argumentos y pulirlos con la elocución, poniéndolos ante los propios ojos lo más vivamente posible; pues de ese modo, al verlos con la mayor claridad y la manera en la que se realizan, se podrá hallar lo conveniente y difícilmente le pasarán inadvertidas las contradicciones (p. 79).

Por otra parte, Webb (1999) afirma que el efecto provocado por la enargeia actúa sobre el estado emocional del oyente, por otra parte, sirve para distinguir a la écfrasis de la narración, porque procura transformar un público oyente en un público espectador.

Se puede afirmar, entonces, que el efecto de la enargeia estará siempre presente en numerosas figuras, tales como el símil, la metáfora y otras, de manera que los procesos adoptados para tenerla son fundamentalmente amplificadores, pues, de este modo estaría contribuyendo a la exégesis del asunto descrito, además de ser más eficaz en la conmoción del público.

En fin, queda de manifiesto que la écfrasis es mucho más que una simple descripción de un objeto de arte y que es la enargeia la que le otorga vivacidad y la acerca a la realidad de hacer visible un objeto ausente para el espectador. Además, la écfrasis inserta en un texto buscará ampliar la significación de este, del mismo modo que lo hace un metarrelato.

\section{La écfrasis de Diana y Acteón como mise en abyme en el libro II de la Metamorfosis (Asno de Oro) de Apuleyo}

Como se manifestó en segmentos anteriores de esta investigación, la écfrasis es concebida como la representación escrita (gráfica) de una obra de arte pictórica, pero no hecha de cualquier manera, sino de tal forma que la descripción realizada mediante la écfrasis, ponga a los ojos del receptor el objetivo descrito.

Sin embargo, para alcanzar tal fin es necesario dotar al género (écfrasis) de mucha enargeia, ya que la fuerza que se le impregne o la vivacidad con la que sea realizada es fundamental para el receptor en el momento de figurarse lo descrito.

Ahora bien, en muchos casos, la écfrasis mostrada en un texto cumple un rol mayor al de la simple descripción, es decir, es colocada o, mejor dicho, dispuesta por el autor de tal manera que amplíe el sentido del texto o la significación de los acontecimientos inscritos en él. Tal es el caso de la écfrasis mostrada en el libro segundo de la Metamorfosis (Asno de oro), la cual es presentada de la siguiente manera: En el atrio, bellísimo, se levantaban en cada una
de las esquinas unos pedestales que sostenían
las efigies de la diosa de la palma con las alas
desplegadas; aún sin movimiento ninguno, como
tenían las rosadas plantas de los pies sobre la
curvatura de una esfera, daba la impresión de que
estaba en vilo. Una estatua de mármol de Paros,
que representaba a Diana, ocupaba el centro del
lugar. Era una imagen de una elegancia superior,
con la túnica al viento, vigorosa, en actitud de
acogimiento a los visitantes, y con la majestuosidad
antigua de la divinidad. A uno y otro lado de
la diosa montaban guardia unos perros de ojos
amenazadores, orejas tiesas, dilatadas narices, y,
fauces abiertas, tan reales, que de sonar cerca un
ladrido, cualquiera pensaría que había salido de
aquellas bocas de mármol. En lo que cifré que el
escultor demostraba mejor la excelencia de su arte
fue en que, mientras los audaces y amenazadores
perros se mantenían apoyados sobre sus patas
traseras, con las de delante parecían estar corriendo.
Por detrás de la diosa sobresalía una roca a modo de
cueva con musgo, hierbas, hojas, brotes pámpanos 
y arbustos que crecían por todas partes. En el interior, la sombra de la estatua se perfilaba sobre la transparencia del mármol. De la parte inferior de la roca colgaban manzanas y uvas, acabadas con tal exactitud, que el arte, a porfía con la naturaleza, había llegado a la perfección, porque cualquiera hubiera creído que se podían coger cuando el otoño les inhalara el color de la madurez. De asomarse a la fuente que fluye a los pies de la diosa con suave corriente, a su reflejo creerías que tampoco les faltaba, entre otros realismos, la apariencia de movimiento que tienen los racimos que penden realmente de una vid. En medio del follaje en piedra aparecía la representación de Acteón ${ }^{2}$, ya medio transformado en ciervo, mirando de solayo a la diosa, y con la vista puesta en los prolegómenos del baño de Diana" (Apuleyo, II.4, p. $74^{3}$ ).

Es considerablemente detallada la écfrasis que Apuleyo desarrolla a través del personaje de su obra Lucio, ya que pone de manifiesto detalles únicamente apreciables por medio de una observación impresionantemente minuciosa.

Ahora bien, ante tal descripción, el punto que atañe a este capítulo es demostrar por qué podría considerarse como mise en abyme o puesta en abismo la écfrasis antes descrita. Un primer indicio sería el hecho de que tanto Lucio en el Asno de Oro como Acteón sufren cambios debido a la curiosidad que ambos poseen, la cual podría ser considerada como un eje central en el texto ya que, si bien es cierto, Acteón es transformado en ciervo por curiosear, durante el baño de la diosa Diana, Lucio sufrirá algo similar debido a su insaciable curiosidad, pues es transformado en asno por los poderes de una maga, a quien ve metamorfosearse en diversos animales. Esta curiosidad queda de manifiesto en la siguiente cita:

Pero, encelado en mi curiosidad de siempre, en cuanto escuché la anhelada palabra del arte de la magia, me vi tan lejos de la prevención que debía tener con Pánfila que, por el contrario, comencé a impacientarme de tanto como deseaba iniciarme en su aprendizaje, costase lo que costase, incluso enechándome a ojos cerrados al cenagal de su precipicio (Apuleyo, II.6, p. $75^{4}$ ).

Es notable, en la cita anterior, cómo la curiosidad presentada por Lucio, y que lo lleva a sufrir la transformación, posee un enorme paralelismo con lo sucedido por Acteón, quien también es castigado debido a su curiosidad. En relación con este pasaje, encontramos entonces una mise en abyme intratextual, es decir, tal como lo menciona Dällenhach (1991) "existe una homologación entre el código y el enunciadoreferente" (p. 96).

Lo anterior quiere decir que la relación entre el código de la escritura (lenguaje verbal) que tenía por función textual que Lucio manifestase su curiosidad, se podría homologar o referenciar con el código de la escultura en tanto se manifiesta que Acteón (en el grupo escultórico descrito) será castigado por Diana, debido a que vio lo que no estaba autorizado para ver.

En resumen, la curiosidad (como punto de contacto y mise en abyme) que invade a Acteón para escabullirse en medio del follaje y deleitarse con la curvilínea silueta de Diana la diosa será un motivo referencial que ampliará al lector la significación del texto de la Metamorfosis, pero, además, le dará una pista para interpretar las acciones de Lucio, así como para darse cuenta de cuál será la suerte de este, en vista de la curiosidad que lo embarga.

Por otra parte, el tema la écfrasis del grupo escultórico sirve de mise en abyme, ya que manifiesta un ambiente de inseguridad en la realidad de los objetos. Esta perspectiva es utilizada a lo largo de todo el texto, pues, al satirizar la sociedad de la época Lucio constantemente hace referencia al juego entre el ser y el parecer.

Esa confusión de lo real con lo que no lo es queda manifestada en el siguiente fragmento:

Yo creía que lo que estaba viendo en aquella ciudad
no era realmente lo que veía, sino que un zumbido
feral había transformado una cosa en otra, de
manera que para mí las piedras en las que tropezaba
eran personas petrificadas, y los pájaros, humanos
hechos pluma; también imaginaba que los árboles
que rodeaban la muralla eran figuras humanas
con hojas, y que las aguas de las fuentes fluían
asimismo de seres humanos (Apuleyo, II 1-2, p. $72^{5}$ ).

Lo anterior, comparado con la descripción del grupo escultórico realizada por Lucio, hace pensar que dicha estatua se encuentra en movimiento o que los elementos que la 
componen no son de piedra, sino que poseen tanta vida como si fueran reales. De ahí que dicha descripción del objeto de arte, donde la escultura se mezcla y se confunde con lo verdadero, con la realidad, es sin duda alguna "puesta en abismo".

La inseguridad de las objetos, es decir, si son parte de la realidad o si son otra cosa, se ve reflejado cuando Lucio menciona acerca del grupo escultórico de Diana y Acteón, que "parece que los perros están a punto de ladrar y de moverse; las uvas son tan reales que podrían tomarse, y los racimos de esta serían capaces de ser agitados por el viento".

De este modo, el juego entre el ser y el parecer se manifiesta desde la écfrasis hecha por Lucio, pues rompe con el espacio escénico y este binomio (ser-parecer) recorrerá el texto desde el libro primero hasta el último, pues es dado en él que, por medio de la sátira, el personaje principal de Metamorfosis (Lucio) critique la sociedad (los diferentes niveles de estamento social) partiendo, justamente, de ese punto de vista.

Unido a lo anterior, y al concepto de écfrasis y metamorfosis, las estatuas pueden observarse como dobles y esto se debe al efecto de las transformaciones producidas por la magia; si se nota bien, el hecho de que la estatua de Diana y Acteón sea tan realista, que incluso sea capaz de engañar a las aves, la reviste de una característica animista recurrente durante toda la obra. En esta obra, y principalmente en la casa de Pánfila, la hechicera, que convierte a Lucio en asno, los objetos cobran vida y las transformaciones son fáciles de notar, tal como se observa en la siguiente cita:

A medida que se agitaba los agitaba (los brazos)
suavemente, fueron brotándole suaves plumones;
luego le crecieron recias plumas, se le endureció la
nariz aguileña y se le cayeron las uñas: Pánfila se
había convertido en búho (Apuleyo: II, p.106).

Las formas son cambiantes, lo que parece real (en realidad) no lo es en su totalidad. Es por dicha razón, que el grupo escultórico de Diana y Acteón resulta sumamente importante en el texto de Apuleyo, ya que la metamorfosis sufrida por Acteón, debido al castigo propinado por Diana, es un reflejo, cual si fuera un espejo, del texto en su completud. La adaptación del mito que hace Apuleyo es idónea, pues, a partir de lo que Lucio describe, se describe a sí mismo y a una serie de personajes, cuya vidas cambiarán o, mejor dicho, se metamorfosearán a lo largo de la trama textual. Puesto de otro modo, el grupo escultórico, como mise en abyme, se convertirá en un espejo de lo enunciado textualmente de tal manera que, en la representación escultórica del mito de Diana y Acteón, se puede leer la historia y el porvenir de Lucio en la Metamorfosis.

\section{4. Écfrasis del grupo escultórico de Diana y Acteón, visto a partir de la enargeia y la esperanza ecfrástica}

Según Aristóteles (2009) en la Poética $^{6}$, las descripciones deben hacerse lo más detalladas posibles, tanto así, que sea posible traer a la vista de alguien un objeto ausente. Visto de esta manera, la enargeia deberá caracterizar toda descripción ecfrástica, ya que, para esta, el detalle es esencial en tanto se trata de reproducir verbalmente un objeto artístico en todas sus dimensiones y pormenores, incluso el más pequeño.

Esto es ratificado por Hermógenes (1991), quien pensaba que toda descripción debía, ante todo, estar fundamentada en el cuidado de cada detalle, de cada rasgo, aún el más insignificante, tal como se muestra en la siguiente cita:

las virtudes de la descripción son principalmente claridad y viveza, pues es necesario que la elocución por medio del oído, casi provoque la visión de lo que se describe (p. 23).

En el libro II de la Metamorfosis, específicamente la descripción hecha por Lucio de la escultura Diana y Acteón que se encontraba en la casa de Birrena, donde estaba hospedado, está cargada de una gran cantidad de enargeia, tanto es así, que los objetos descritos a pesar de ser estáticos, se revisten de cierta animación 
dada por Lucio para manifestar la impresionante habilidad con que fue construida dicha escultura. Tal destreza se observa en la siguiente cita:

En lo que cifré que el escultor demostraba mejor la excelencia de su arte fue en que, mientras los audaces y amenazadores perros se mantenían apoyados sobre sus patas traseras, con las de adelante parecían estar corriendo (...) De la parte inferior de la roca colgaban manzanas y uvas, acabadas con tal exactitud, que el arte, a porfía con la naturaleza, había llegado a la perfección (...) De asomarse a la fuente que fluye a los pies (...) a su reflejo creerías que tampoco les faltaba, entre otros realismos, la apariencia de movimiento que tienen los racimos que penden realmente de una vid (Apuleyo, 2008: 74).

En la aplicación de la enargeia, tal como se pudo observar en la cita anterior, se encuentran amalgamadas dos condiciones esenciales: Por una parte, se encuentran las relaciones físicas del objeto (el grupo escultórico) y por otra, se puede dilucidar la relación que este posee con el medio en que se encuentra, y con Lucio, quien revela cada una de las partes del objeto. Esta conjunción solo es factible si la apreciación del que se encuentra describiendo el objeto media entre el hecho descriptivo y lo que se describe.

De este modo, comprendiendo la descripción así, se observaría que esta se encontraría apartándose de una fiel representación del referente para convertirse en una especie de interpretación de lo descrito de tal modo la descripción hecha por Lucio en la cita anterior, no solo sería una caracterización de un objeto fijo, sino, por el contrario, se trataría de un análisis de las formas de dicho objeto, realizado con el fin de comprenderlo y así brindar una interpretación que le ayude al lector a imaginarlo.

Es impresionante cómo la descripción hecha por Lucio propone una eliminación de las barreras entre lo real y lo ficticio. La enargeia contenida en la descripción del grupo escultórico hace pensar en una obra tan impresionantemente bella y bien terminada, que podría tratarse de algo real e incluso vivo.
Los apretados límites existentes entre fantasía y enargeia fueron punto de discusión una y otra vez, de los retóricos de la Antigüedad. Sin embargo, la fantasía es una característica fundamental, o mejor dicho, necesaria, para el discurso ecfrástico. De esa manera, el hecho de que Lucio, en la descripción que hace de la escultura de Diana y Acteón, la cual muestra como una estatua perfecta (incluso digna de confundir a las aves con el refinamiento de sus formas o de parecer tener movimiento en las acciones mostradas), intenta elevarla por medio de la enargeia y proporcionarle al discurso un sentido extraordinario o excelso. Las imágenes descritas en la cita, son sumamente idóneas para dotar a la écfrasis, hecha por Lucio, de un estilo magnificente, esplendoroso y, por supuesto, henchido de enargeia.

De tal manera que, al poner ante ojos del lector la escultura de Diana y Acteón, Lucio (mediante la écfrasis) muestra el carácter realista del arte, pero no solo eso, también propone que el arte, o mejor dicho, la écfrasis de ese arte puede llegar a ser igual a la obra misma o incluso superarla. Esto se llama esperanza ecfrástica, en la cual según Mitchell (2009):

la imposibilidad de la écfrasis se supera con la imaginación o la metáfora, cuando descubrimos que existe un sentido en que el lenguaje puede hacer aquello que muchos escritores han querido hacernos ver (p. 138).

En efecto, el hecho de que Lucio compare los racimos de uvas y de manzanas de la escultura, con los reales, hace notorio el uso de metáforas que dan dos posibilidades: Por un lado, busca homologar el trabajo del escultor con la realidad; la escultura que describe no es como cualquier otra, es tan perfecta que podría confundirse con los personajes del mito, es decir, la escultura no es la representación de los personajes en toda su integridad sino se convierte en los personajes mismos. El arte aquí cumple con una característica muy estimada en la antigüedad, la de imitar tan bien lo real, que incluso llegue a ser como el original. 
Por otra parte, al hacer una descripción tan detallada del grupo escultórico; Lucio pretende dejar en claro cada aspecto de la escultura. Con esto, sin darse cuenta, está observando y describiendo su propio futuro, es decir, al describir lo que le sucede a Acteón por observar la desnuda figura de Diana en momentos en que esta tomaba un baño, Lucio sin saber, observa lo que le sucederá, siendo esto, el castigo de sufrir una metamorfosis por causa de su curiosidad.

De este modo, Apuleyo, al colocar en palabras de Lucio la descripción de la escultura la convierte en un espejo donde se ve reflejada la historia del personaje (Lucio) y la trama textual de la obra en general, pues las metamorfosis ocurren en todo momento producto de la magia manifiesta en Pánfila y su ayudante, y entre algunos otros personajes femeninos presentes en el texto. Unido a lo anterior, se estaría proyectando una característica esencial de la enargeia, a partir del discurso de Lucio. Esta sería que esta no es tanto un elemento intrínseco a la lengua, sino que radica en cuanto a la habilidad que posea quien enuncia la descripción. Por lo tanto, si bien es cierto que el personaje principal del Asno de oro realiza una retrato hablado de la escultura de Diana y Acteón. en la que es posible interpretar que se trata de la descripción de la vida futura de este, son las palabras escogidas y la manera en la que se desarrolla la descripción, las que hacen pensar eso.

De ese modo, la destreza en la elección de las palabras indicadas y la capacidad imaginativa formarán una amalgama indisoluble y sumamente importante a la hora de producir la imagen visual por medio de las palabras.

La enargeia adquiere, de esta manera, una importancia enorme en la descripción de los elementos del grupo escultórico de Diana y Acteón, pues en ella estriba el impacto que tenga en el lector o auditor y la interpretación que estos puedan darle.

Por otra parte, al permitir (la enargeia) que se pueda interpretar una determinada descripción, esta dirige su atención hacia la amplificación de los sentidos del oyente y las circunstancias en que dicha descripción se da. El oyente no solo se convierte en un testigo de lo descrito por el narrador sino que también podrá figurarse lo que sucederá con quien narró la descripción del objeto.

En este sentido, la écfrasis que hace Lucio da para mucho más que limitarla únicamente a considerarla écfrasis. Gracias a la enargeia puesta en la descripción también es considerada mise en abyme en el primer apartado, cumple rasgos sumamente notorios tales como la función de espejo del personajes protagonista, quien sin saberlo es reflejado por Acteón en tanto los dos serán metamorfoseados por ver lo prohibido.

En fin, la potencia de la enargeia tiene como resultado no solo la adhesión del auditorio, sino la del propio Lucio que está atrapado y representado en la imagen visual que ha creado.

\section{Consideraciones finales}

La descripción que Lucio hace del grupo escultórico de Diana y Acteón es realizada con una gran potencialidad en cuanto a enargeia, ya que esa escultura deja de ser solo una representación para convertirse en un objeto real. Además, al poseer mucha enargeia, cumple con lo mencionado por Hermógenes acerca de que las descripciones deben poseer claridad y viveza para hacer que un objeto ausente se vuelva presente ante los ojos de quien percibe la descripción.

La écfrasis presente en el libro II del Metamorfosis funciona como mise en abyme, ya que refleja la historia de Lucio, quien, al igual que Acteón, sufrirá una metamorfosis debido a la curiosidad.

La enargeia es indispensable para toda descripción ecfrástica, ya que sin ella, no sería posible superar la imposibilidad de traer a la vista y la imaginación de otro un objeto que no está presente y, con ello, el concepto de esperanza ecfrástica sería simplemente desechado.

Finalmente la écfrasis es más que un elemento retórico; es todo un género digno de estudio en vista de que lucha permanentemente por describir los objetos artísticos de tal manera que incluso los iguale o los supere. 


\section{Referencias bibliográficas}

Apuleyo. 2008. El asno de oro. Madrid: Catedra.

Aristóteles. 2009. La poética. Madrid: Alianza Editorial.

Beristáin, E. 1995. Diccionario de Retórica. México: Purrúa.

Bonilla, E. y Rodríguez, P. 1997. Más allá del dilema de los métodos. Bogotá, Colombia: Norma.

Dällenbach, L. 1991. El relato espectacular. Madrid: Visor.

Gabrielle, J. 2005. Prismas descriptivos y las cárceles. Efecto de espejo y la puesta en abismo en Don Quijote. Washigton: Heldref Publications.

Masón, J. 1996. Investigación cualitativa. Londres, Inglaterra: Sage.

Mendizábal, N. 2006. Los componentes del diseño flexible en la investigación cualitativa. En: Estrategias de investigación cualitativa. Barcelona, España: Gedisa.
Meyer, M. La mise en abyme en narratologie. Recuperado de http// www.vox.poetica.org/t/ menabyme (acceso 13 de abril de 2011).

Mitchell, W. J.T. 2009. La ekphrasis y el otro. En Teoría de la imagen: ensayos sobre representación verbal y visual. Madrid: Akal.

Pineda, V. 2000. La invención de la écfrasis. Homenaje a la profesora Carmen Pérez Romero. Universidad del Extremadura, Facultad de Filosofía y Letras.

Spitzer, L. 1967. The "Ode on a Greciam Urn" or content vs metagrammar". Princetón, Princetón University Press.

Taylor, S.J. y Bodgan, R. 1990. Introducción a los métodos cualitativos de la investigación. La búsqueda de significados. Buenos Aires, Argentina: Paidós.

Webb, R. 1999. The aesthetics of sacred space: narrative, metaphor, and motion. En: Ekphraseis of Church Buildings: Durbarton Oaks Papers, Vol 53.

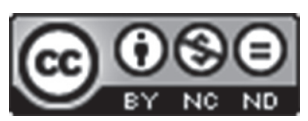

Este obra está bajo una licencia de Creative Commons Reconocimiento-NoComercial-SinObraDerivada 4.0 Internacional. 